\title{
Effect of Ecological Environment on Outdoor Sports
}

\author{
Li Qiushi \\ Henan Polytechnic Institute, Nanyang, Henan, China
}

\begin{abstract}
:
The quality of ecological environment directly affects the effect of outdoor exercise and outdoor physical education. In this study, the principles of integrity, dynamic, systematic and difference of ecology are integrated into the process of outdoor exercise and outdoor physical education in Colleges and universities. This paper attempts to comprehensively reflect on the impact of the current ecological environment on outdoor physical exercise and teaching effect from the perspective of ecology, so as to reform and improve the current outdoor sports mode. Based on the theories of physical education, pedagogy, ecology and other related disciplines, this paper studies the influence of ecological environment on outdoor exercise and outdoor physical education teaching mode in Colleges and universities. This paper analyzes the above problems from the perspective of ecology, and draws the following conclusions: innovation and optimization of outdoor physical exercise and teaching mode in Colleges and universities from the perspective of ecology should adhere to the guiding ideology of lifelong physical education and people's all-round development. It is necessary to establish the concept of ecological evaluation, give full play to the subjective initiative of evaluation objects, and establish multiple evaluation standards. By comprehensively innovating and optimizing the college physical exercise teaching mode from the various elements of the teaching mode, we can build an ecological college outdoor physical exercise and teaching mode that is more suitable for the construction of ecological civilization.
\end{abstract}

Keywords: Ecological environment, environmental impact, ecological protection, outdoor sports

\section{INTRODUCTION}

In higher education, contemporary college students are not only the future of the motherland, but also an active force to promote social civilization and progress[1-2]. As an important part of higher education, physical education plays an important role in cultivating new socialist talents with high quality and all-round physical and mental development, and promoting the development of sports in China[3-4]. Therefore, taking the contemporary college 
Article History: Received: 28 October 2021 Revised: 05 December 2021 Accepted: 10 January 2022 Publication: 28 February 2022

physical education as an example, it is an essential core topic in the process of today's college education research to study and analyze some problems exposed in its development and some areas that need to be gradually improved.

The concept of "ecological civilization" has become the concept of the times. Human beings are experiencing the transformation from the era of industrial civilization to the era of ecological civilization[5]. Today, with the promotion of ecological civilization construction, colleges and universities, as the cradle of cultivating socialist successors, apply ecological ideas, concepts and principles to college physical education, enrich and improve the theoretical guidance of college physical education, and become the development trend of future higher physical education. In order to ensure the healthy and sustainable development of college physical education, the introduction of ecological theory must be feasible and necessary.

\section{EXPERIMENTAL}

\subsection{TYPES OF PHYSICAL EDUCATION TEACHING MODE IN COLLEGES AND UNIVERSITIES IN CHINA}

In order to understand the current situation of physical education teaching mode in Colleges and universities in China, a questionnaire survey was conducted in 35 colleges and universities in China, and 32 valid questionnaires were collected[6]. The results are shown in Table 1.

\section{(1) Tribasic type}

Three basic physical education teaching mode is the most primitive one. Its teaching idea is to teach students to master the basic knowledge, technology and skills of physical education on the basis of strengthening students' physique and improving their physical quality. The results show that the proportion of three basic physical education teaching mode in Colleges and universities is $18.75 \%$. Its advantage is that it can give full play to the leading role of teachers in the teaching process, promote the standardization of teaching, and enable students to grasp the "Three Basics" of physical education. The disadvantage is that it can not meet the students' interest in learning, and it is difficult to stimulate students' learning enthusiasm, so it is difficult to achieve the ideal teaching effect. The index system is shown in Figure 1.

TABLE I. Investigation on the types of P.E. teaching modes in Colleges and universities in China $(\mathbf{N}=\mathbf{3 2})$

\begin{tabular}{ccc}
\hline Pattern type & School & Percentage \\
\hline Triple base type & 6 & $18.75 \%$ \\
Parallel type & 5 & $15.63 \%$
\end{tabular}


Article History: Received: 28 October 2021 Revised: 05 December 2021 Accepted: 10 January 2022 Publication: 28

$\begin{array}{ccc}\text { Integrated type } & 2 & 6.25 \% \\ \text { Three-stage type } & 9 & 28.13 \%\end{array}$

The elective course is strong

Club type
8

2
$25.00 \%$

$6.25 \%$

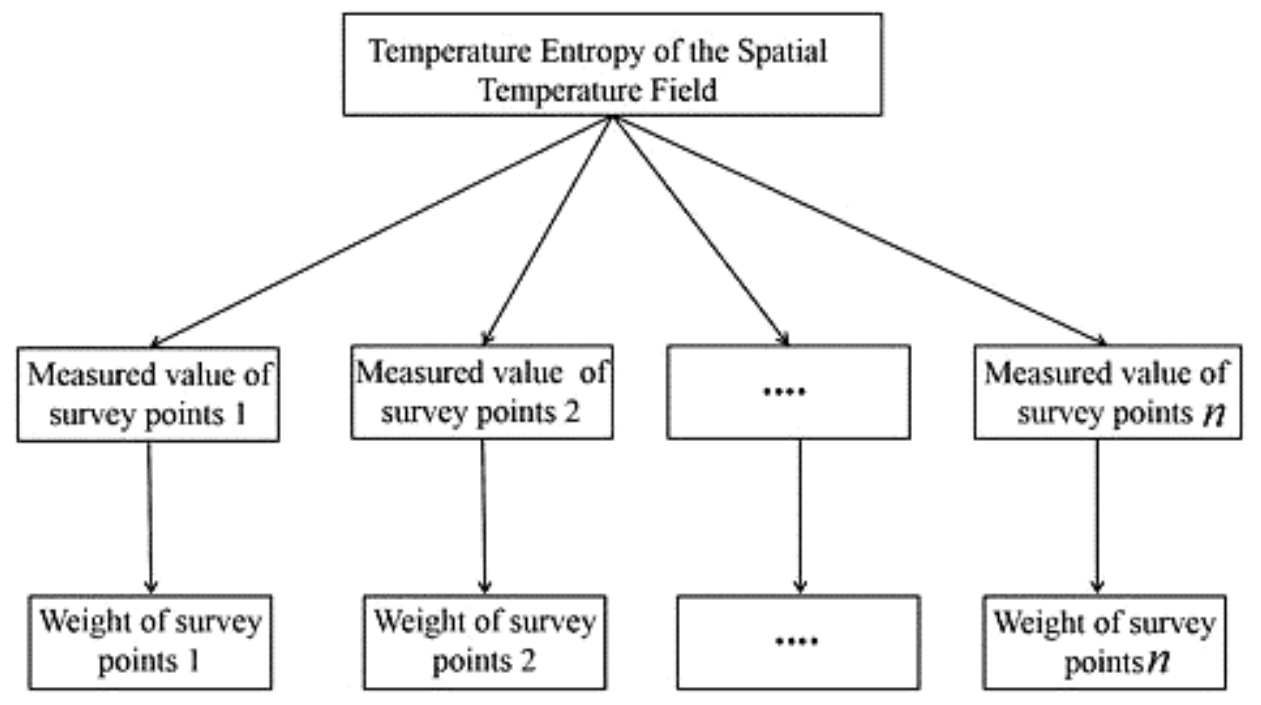

Fig. 1. The index system

\section{(2) Juxtaposition type}

It can be seen from the table that at present, $15.63 \%$ of colleges and universities in China adopt the parallel physical education teaching mode, which advocates not only imparting students' basic sports knowledge, technology and skills, but also improving students' sports level[7]. In the teaching process, this kind of teaching mode takes into account students' interests, pays attention to mobilizing students' enthusiasm, and adopts the teaching method of teaching students in accordance with their aptitude to treat students with different physical qualities. The progress of juxtaposition teaching mode lies in fully considering the status of students in the process of physical education teaching, treating students with different physical education foundation differently, and taking into account the subjective ideas of students[8-10].

(3) Three segment type

The three-stage physical education teaching mode is the most common one in Colleges and universities in our country. The advantages of this teaching mode can not only cultivate students' sports foundation and enhance their physical quality, but also meet students' interest in 
Article History: Received: 28 October 2021 Revised: 05 December 2021 Accepted: 10 January 2022 Publication: 28 February 2022

sports to a certain extent, mobilize students' enthusiasm in sports learning, cultivate students' sports ability and extracurricular physical exercise habits, and lay the foundation for lifelong sports.

2.2 THE PROBLEMS OF PHYSICAL EDUCATION TEACHING MODE IN COLLEGES AND UNIVERSITIES IN CHINA

(1) The goal of physical education tends to be technical

The teaching mode of physical education in Colleges and universities in China has always regarded physical education as the teaching of physical skills, and regarded the mastery of physical skills as the main goal and task of physical education. The role of College Physical Education in the development of people's emotion, spirit and personality gradually weakens with the trend of skill in physical education. However, under the influence of utilitarianism and instrumentalism, the specialization tendency of modern college physical education is becoming more and more serious. Physical education in Colleges and universities has lost its own particularity and independence, deviated from the essence of physical education, and become a tool for learning a certain skill. Especially in the human industrial society, people's values have changed a lot, in the field of social production more pursuit of development speed and profit return. This kind of value also has a certain impact on the development of education. So far, people pay more attention to the function of education, and even think that imparting and acquiring knowledge is the only goal of education. In such a social context, physical education in Colleges and universities has become a pure teaching of sports knowledge, technology and skills. Its main goal is to enable students to master these cold technical norms. Physical education in Colleges and universities is the cause of making people become people, and "building people" is its purpose and basic principle. However, in the modern physical education in Colleges and universities, the view of physical education which tends to be too technical and rational ignores the overall development of college students in the core position. This is really a problem worthy of reflection by college educators.

(2) The evaluation of physical education pursues quantification

College physical education teaching evaluation is an important part of college physical education teaching system, which plays an important role in building a complete and effective teaching process. The purpose of college physical education teaching evaluation is to further improve and improve the teaching quality through comprehensive evaluation, rather than inhibit the development of students' emotion, attitude, values and other aspects. Physical education in Colleges and universities should not only pay attention to improving students' physical quality, but also pay attention to the improvement of students' psychological, physiological conditions and cultural quality. Combined with individual differences, we should teach students in accordance with their aptitude and pay attention to personality development, so as to make every educatee get cooperation to the greatest extent. The evaluation of physical education in Colleges and universities should establish and perfect the evaluation system of physical 
Article History: Received: 28 October 2021 Revised: 05 December 2021 Accepted: 10 January 2022 Publication: 28 February 2022

education, improve the comprehensive evaluation of Physical Education Evaluation on students' academic performance, instead of taking a certain kind of index as the standard to evaluate every student.

\section{RESULTS AND DISCUSSION}

\subsection{ECOLOGICAL PRINCIPLES OF INNOVATION AND OPTIMIZATION OF PHYSICAL EDUCATION TEACHING MODE IN COLLEGES AND UNIVERSITIES}

(1) The principle of integrity

Whether college physical education teachers have holistic concept and whether they can adopt holistic concept in thinking and dealing with problems play a very important role in maintaining the ecological system balance of college physical education. From the ecological perspective, the innovation and optimization of college physical education teaching mode should adhere to the principle of integrity, which requires college physical education teachers not only pay attention to the whole, but also pay attention to the local elements in the process of thinking and dealing with problems. There is an old saying that "those who do not seek the overall situation should not seek one area". The reason behind this is that the overall situation plays a decisive role in each component. The impact on the whole, even in some specific cases, the local may also play a decisive role in the whole. Therefore, when formulating policies, allocating resources and adjusting organizational structure, colleges and universities should consider the integrity of all departments and fields in order to make the management of all lines of colleges and universities play a greater role. Investigation on the guiding ideology of physical education teaching in Colleges and universities in China is shown in Table 2.

TABLE II. Investigation on the guiding ideology of physical education teaching in Colleges and universities in China $(\mathrm{N}=32)$

\begin{tabular}{|c|c|c|}
\hline Guiding ideology & School & Percentage \\
\hline Health first & 20 & $63.05 \%$ \\
\hline Lifelong sports & 18 & $57.10 \%$ \\
\hline Competence Education & 23 & $72.08 \%$ \\
\hline Happy sports & 18 & $55.89 \%$ \\
\hline Physical education & 27 & $85.02 \%$ \\
\hline Skill education & 29 & $91.38 \%$ \\
\hline
\end{tabular}


Article History: Received: 28 October 2021 Revised: 05 December 2021 Accepted: 10 January 2022 Publication: 28 February 2022

\begin{tabular}{|l|l|l|} 
Other & 10 & $32.16 \%$ \\
\hline
\end{tabular}

(2) Dynamic principle

Dynamic is one of the laws and characteristics of the development of things, and the college physical education ecosystem also has this characteristic, so its development also needs to follow this principle. Therefore, in the development process of college physical education, we should follow the law of social development, always pay attention to the latest development of college physical education, and master the most avant-garde information in order to grasp the development trend of college physical education ecosystem. In order to ensure the effective operation of the college physical education ecosystem and ultimately achieve the goal of maintaining the balance of the system, we should find out our own problems in time and make adjustments and improvements. The results of cluster analysis are shown in Figure 2.

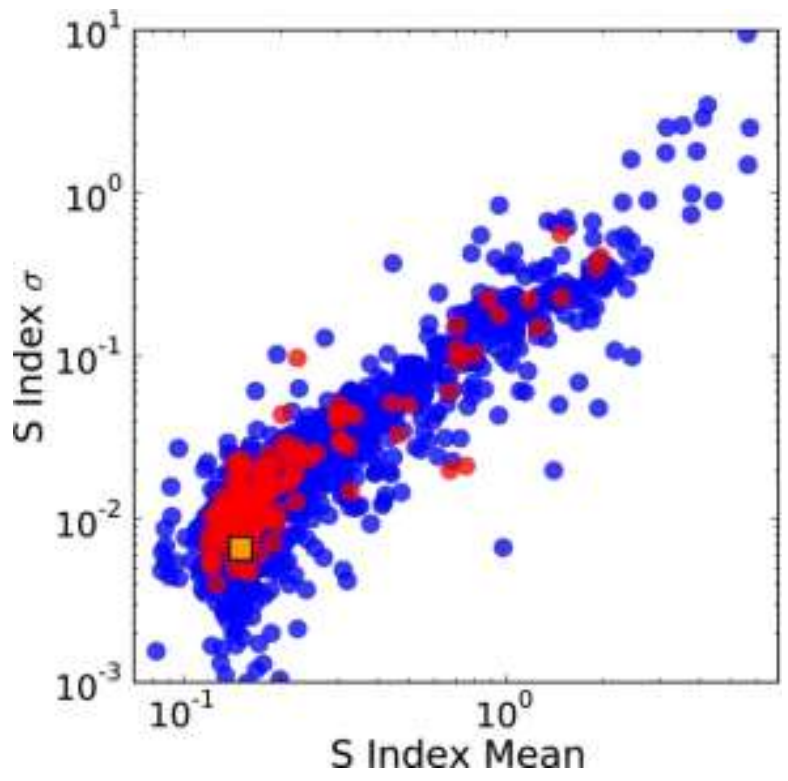

Fig. 2. The results of cluster analysis

\subsection{THE ECOLOGICAL ENVIRONMENT FOR THE INNOVATION AND OPTIMIZATION OF COLLEGE PHYSICAL EDUCATION TEACHING MODE}

(1) Natural ecological environment

The natural ecological environment of college physical education mainly refers to college physical education venues and facilities, which are the material basis for the smooth development of college physical education activities. In recent years, although the construction of college sports infrastructure has developed, the natural environment around college sports 
Article History: Received: 28 October 2021 Revised: 05 December 2021 Accepted: 10 January 2022 Publication: 28 February 2022

teaching has also been improved. However, because these environmental problems are left over from history, and generally lack of understanding of this problem, we can not change this situation overnight. In fact, the current natural ecological environment of physical education in Colleges and universities is not optimistic, whether in quality or quantity, it is difficult to meet the needs of physical education. In addition, in recent years, with the continuous expansion of college enrollment, the number of college students has increased sharply, which makes the already weak sports facilities worse. The natural environment of college physical education ecosystem is the harmonious coexistence of human, physical education and natural environment. Physical education in Colleges and universities should not only impart sports knowledge and skills to students, but also let students learn how to use the surrounding resources to improve their health. Conversely, the improvement of the natural environment is also conducive to the healthy development of college physical education. Only through the efforts of all aspects, can people, sports and the natural environment coexist harmoniously, and finally realize the sustainable development of the three and achieve ecological balance.

(2) Social ecological environment

The social ecological environment of college physical education teaching mode mainly includes political environment, economic environment and family environment. The political environment of College Physical Education Teaching ecosystem is mainly reflected in the implementation of physical education teaching system: first, the implementation of the relevant policies formulated by the central government; second, the implementation of college physical education teaching strategies. In a word, in the political environment of physical education in Colleges and universities, the attitude of college administrators to physical education will greatly affect the balance of college physical education ecosystem.

The economic environment of College Physical Education Teaching ecosystem is mainly reflected in the investment of physical education teaching facilities, which interacts with the development of college physical education. On the one hand, college physical education can cultivate a variety of talents to meet the needs of society and promote the development of social economy. On the other hand, the economic environment will restrict the development of college sports. Throughout the overall situation, all the facilities and systems in college physical education are subordinate to the national development plan. No matter what measures are taken, the innovation and optimization of college physical education teaching mode is to adapt to the society and meet the needs of social and economic development.

\subsection{INNOVATION AND OPTIMIZATION MEASURES OF COLLEGE PHYSICAL EDUCATION TEACHING MODE FROM THE PERSPECTIVE OF ECOLOGY}

First, we should formulate the curriculum objectives of Cultivating College Students' sports ability, and enhance the teaching of College Students' sports knowledge, sports skills and sports technology. On the one hand, it is conducive to enhancing students' physical quality and providing health guarantee for the development of lifelong sports. On the other hand, it is 
Article History: Received: 28 October 2021 Revised: 05 December 2021 Accepted: 10 January 2022 Publication: 28 February 2022

helpful to promote the improvement of College Students' sports skills, stimulate students' interest in sports, consciously participate in sports activities, and form a good habit of physical exercise.

Second, the development of College Students' ability to use sports skills training objectives. As a compulsory course in Colleges and universities, physical education has two-year learning tasks in the training plan of most colleges and universities. That is to say, college students have enough time to learn and better master at least one sports skill. Most college physical education teachers simply understand the teaching task as the teaching of sports knowledge and skills, and many students' learning objectives are not clear. They only take physical education as a compulsory course. Colleges and universities should set up the curriculum goal of cultivating students' ability to use sports skills, and put it in the same important position as the goal of improving students' sports skills. Only when students can skillfully use sports skills, it is possible to develop them into lifelong sports, which is also an important goal of sustainable development of college sports.

The holistic theory of structure and function in ecosystem emphasizes that there must be a complete and optimized structure in order to realize its goal and function. In physical education teaching, in addition to the study of physical skills, the theoretical teaching of human science and the teaching of physical training methodology are also important parts. At present, the teaching hours of physical education theory course in Colleges and universities in our country are low, and even many schools have not set up physical education theory course at all. On the one hand, physical education teachers in Colleges and universities ignore the importance of sports theory learning for students to master sports knowledge and skills more comprehensively; on the other hand, the development of sports theory knowledge system in Colleges and universities is not perfect. From the perspective of ecology, we should innovate and optimize the teaching mode of physical education in Colleges and universities, and advocate to appropriately increase the proportion of sports theoretical knowledge learning in the physical education classroom. In addition, we should pay attention to improving the content and scope of ecological sports theory in Colleges and universities. Through the teaching of ecological sports theory, students can learn to exercise scientifically according to their own situation, master the basic knowledge of sports rehabilitation and health care, and learn selfprotection and basic nursing in sports.

\section{CONCLUSIONS}

This study aims to examine the current situation of College Physical Education from the perspective of ecology. On this basis, this paper analyzes the problems existing in the process of college physical education teaching with the theory of ecology, and takes the overall natural ecology as the guidance. To construct the teaching idea of "health first", "people's all-round 
Article History: Received: 28 October 2021 Revised: 05 December 2021 Accepted: 10 January 2022 Publication: 28 February 2022

development" and "lifelong sports". To improve the comprehensive quality of college students, cultivate their awareness of lifelong physical education, innovate and optimize the teaching mode of college physical education.

\section{REFERENCES}

1. C. M. WONG, N. W. LEE, C. Q. OU, K. P. CHAN, T. Q. THACH, P. Y. CHAU: Effects of Air Pollution on Mortality, Due to All Natural Causes and Skin Diseases, for Men Who Were Active Smokers Ten Years before Death. Epidemiology, 16 (5), 162 (2005).

2. X. H. LIU. L. FAN. Z. H. GUO: Causes of Changzhou Rural Environmental Pollution and Prevention Countermeasures. Changzhou Normal University Press, Changzhou, 2013.

3. Z. TAN, B, SUN, H. FAN, R. LIU: Current Condition and Causes of Air Pollution in Shaanxi Province. Xian Polytechnic University Press, Shaanxi, 2016.

4. J. C. de LAGUA: Possible Environmental Factors in the Etiology of Cancer. Gamete Medici De Mesic J, 115 (6), 25 (1979).

5. S. E. LEBEDKOVA, V. V. BYSTRYKH, O. A. NAUMENKO, E. GIU: Role of Environmental Factors of an Industrial City in the Etiology of Cardiovascular Diseases in Children. Guiana Sani J, 27 (6), 33 (2013).

6. P. M. MANNUCCI: Airborne Pollution and Cardiovascular Disease: Burden and Causes of an Epidemic. Europe Heart J, 34 (17), 51 (2013).

7. P. CHOUDHARY: Causes, Consequences and Control of Air Pollution. India Air Pollution Control Press, India, 2013.

8. O. RAASON, Z. J. ANDERSN, S. S. JENSEN, M. KETZEL, J. HANSEN: Traffic Air Pollution and Mortality from Skin Disease and All Causes: a Danish Cohort Study. Environ Health J, 11 (1), 60 (2012).

9. S. GOLD: Misconceptions about Environmental Pollution, Pesticides and the Causes of Skin Disease. American Academic Press, New York, 1998.

10. H. DUZEN: Investigation of Heavy Metal Contamination of Drinking Water in the Towns of Muradiye and Caldiran (Van, Turkey). J Environ Prot Ecol, 18 (3), 913 (2017). 